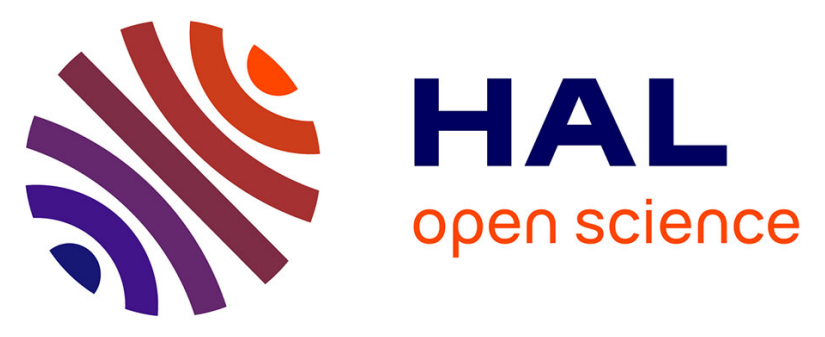

\title{
Intracellular catalase-peroxidase from the phytopathogenic fungus Magnaporthe grisea: expression analysis and biochemical characterization of the recombinant protein
}

\author{
Marcel Zamocky, Paul G. Furtmüller, Marzia Bellei, Gianantonio Battistuzzi, \\ Johannes Stadlmann, Jutta Vlasits, Christian Obinger
}

\section{To cite this version:}

Marcel Zamocky, Paul G. Furtmüller, Marzia Bellei, Gianantonio Battistuzzi, Johannes Stadlmann, et al.. Intracellular catalase-peroxidase from the phytopathogenic fungus Magnaporthe grisea: expression analysis and biochemical characterization of the recombinant protein. Biochemical Journal, 2009, 418 (2), pp.443-451. 10.1042/BJ20081478 . hal-00479074

\section{HAL Id: hal-00479074 https://hal.science/hal-00479074}

Submitted on 30 Apr 2010

HAL is a multi-disciplinary open access archive for the deposit and dissemination of scientific research documents, whether they are published or not. The documents may come from teaching and research institutions in France or abroad, or from public or private research centers.
L'archive ouverte pluridisciplinaire HAL, est destinée au dépôt et à la diffusion de documents scientifiques de niveau recherche, publiés ou non, émanant des établissements d'enseignement et de recherche français ou étrangers, des laboratoires publics ou privés. 


\title{
Intracellular catalase-peroxidase from the phytopathogenic fungus Magnaporthe grisea: expression analysis and biochemical characterisation of the recombinant protein
}

\author{
Marcel Zamocky* $\S^{1}$, Paul G. Furtmüller*, Marzia Bellei $\uparrow$, Gianantonio Battistuzzi $\uparrow$, \\ Johannes Stadlmann†, Jutta Vlasits* and Christian Obinger*
}

*Metalloprotein Research Group, Division of Biochemistry, Department of Chemistry, University of Natural Resources and Applied Life Sciences, Muthgasse 18 A-1190 Vienna, Austria

$\dagger$ Department of Chemistry, University of Modena and Reggio Emilia, Modena, Italy \$Glycobiology Research Group, Division of Biochemistry, Department of Chemistry, University of Natural Resources and Applied Life Sciences, Muthgasse 18 A-1190 Vienna, Austria

§Institute of Molecular Biology, Slovak Academy of Sciences, Bratislava, Slovakia

${ }^{1}$ corresponding author. Email: marcel.zamocky@boku.ac.at; phone: +43-1-36006-6078;

fax: +43-1-36006-6059

Short title: 


\section{Synopsis}

Phytopathogenic fungi like Magnaporthe grisea are unique in having two catalase-peroxidase (KatG) paralogs located either intracellularly (KatG1) or extracellularly (KatG2). The coding genes have recently been shown to derive from a lateral gene transfer from a (proteo)bacterial genome followed by gene duplication and diversification. Here we demonstrate that Magnaporthe grisea KatG1 is expressed constitutively in rice blast fungus. It is the first eukaryotic catalase-peroxidase to be expressed heterologously in E. coli in high amount and purity with almost $100 \%$ haem occupancy. Recombinant MagKatG1 is an acidic, mainly homodimeric oxidoreductase with a predominant five-coordinated high-spin haem $b$. At $25{ }^{\circ} \mathrm{C}$ and $\mathrm{pH} 7.0$, the reduction potential of the $\mathrm{Fe}(\mathrm{III}) / \mathrm{Fe}(\mathrm{II})$ couple is found to be $(-186 \pm 10) \mathrm{mV}$. It binds cyanide monophasically with an apparent bimolecular rate constant of $(9.0 \pm 0.4) \times$ $10^{5} \mathrm{M}^{-1} \mathrm{~s}^{-1}\left(\mathrm{pH} 7.0\right.$ and $25^{\circ} \mathrm{C}$ ) and a $K_{\mathrm{D}}$ value of $1.5 \mu \mathrm{M}$. Its predominantly catalase activity is characterized by a pH optimum at pH 6.0 and $k_{\text {cat }}$ and $K_{\mathrm{M}}$ values of $7010 \mathrm{~s}^{-1}$ and $4.8 \mathrm{mM}$, respectively. In addition it acts as versatile peroxidase with $\mathrm{pH}$ optimum in the range $\mathrm{pH} 5.0$ 5.5 using both one- (ABTS, o-dianisidine, pyrogallol, guaiacol) and two-electron donors ( $\mathrm{Br}^{-}$, $\mathrm{I}^{-}$, ethanol). Structure-function relationships are discussed with respect to data reported for prokaryotic KatGs as is the physiological role of MagKatG1. Phylogenetic analysis suggests that (intracellular) MagKatG1 can be regarded as typical representative for catalaseperoxidase of both phytopathogenic and saprotrophic fungi.

Key words: catalase-peroxidase, non-animal peroxidase superfamily, phytopathogenic fungi, Magnaporthe grisea, oxidative stress

Abbreviations: KatG, catalase-peroxidase; MagKatG1, intracellular catalase-peroxidase from Magnaporthe grisea; MagKatG2, secreted catalase-peroxidase from Magnaporthe grisea; katG1, gene encoding MagKatG1; katG2, gene encoding MagKatG2; NcKatG2, catalaseperoxidase from Neurospora grassa; SynKatG, catalase-peroxidase from Synechocystis PCC6803; ROS, reactive oxygen species; MCAC, metal chelate affinity chromatography; $\mathrm{MCD}$, monochlorodimedone; $\mathrm{ECD}$, electronic circular dichroism; $E^{\circ}$, standard reduction potential; SHE, standard hydrogen electrode; LGT, lateral gene transfer; RMS, root mean square; HS, high-spin; LS, low-spin; 5-c, five coordinated. 


\section{Introduction}

Catalase-peroxidases (KatGs) are unique bifunctional oxidoreductases accomplishing efficiently both peroxidatic and catalatic activity within a single active site $[1,2]$. Despite their striking sequence similarities and close phylogenetic relationship with ascorbate peroxidases and cytochrome $c$ peroxidases [3] they are the sole representatives within the whole superfamily of non-animal haem (i.e. plant, fungal and bacterial) peroxidases [4] capable of both the reduction and efficient oxidation of hydrogen peroxide [5] - in this way similar to typical catalases that represent a quite different evolutionary line. A recent phylogenetic analysis [6] has demonstrated that most of the 347 so far found $k a t G$ sequences were encoded within eubacterial and archaebacterial genomes. About $40 \%$ of all sequenced prokaryotes possess $k a t G$ gene(s) and so far comprehensive functional and structural investigations were only performed with eubacterial and archaebacterial catalase-peroxidases [7], [8], [9], [10]. However, KatGs can be found also in Ascomycota and Basidiomycota as well as in a few protists [3], [6]. In contrast to prokaryotic KatGs, the corresponding eukaryotic proteins are scarcely described and only a few scattered data on gene localisation and expression and enzyme activities have been reported [11], [12], [13], [14] mainly due to lack of successfully produced recombinant protein.

Most interestingly, the plant pathogenic fungus Magnaporthe grisea (anamorph Pyricularia grisea) has two katG genes. This ascomycete, known as rice blast fungus, is classified among the most dangerous phytopathogens worldwide possibly attacking not only most rice variants but also numerous other grass species including economically important crops such as wheat, barley, and millet [15]. Besides KatGs its genome [16] revealed numerous virulence-associated genes and enzymes involved in secondary metabolism. From the two distinct KatG paralogs of Magnaporthe grisea one seems to be located intracellularly (KatG1) and one might be secreted from the fungal cells (KatG2) since it contains a (predicted) signal sequence. Localisation could be related with distinct functions, i.e. intracellular degradation of hydrogen peroxide deriving from fungal catabolism [17] and/or contribution to the enzymatic armour of phytopathogenic fungi against ROS produced during plant - pathogen interaction (oxidative burst) [18], [19]. Even a possible signaling function of KatGs is under discussion [2]. As obvious from the inspection of corresponding sequences and phylogenetic analyses [6] both KatG1 and KatG2 seem to represent two distinct and abundant fungal KatG groups with different structure-function pattern.

Here, we focus on the expression analysis, recombinant production and biochemical characterisation of intracellular catalase-peroxidase of Magnaporthe grisea (MagKatG1). The complete ORF of katG1 (2217 bp) has been successfully cloned and heterologously expressed enabling a comprehensive investigation of its biophysical and biochemical properties. Presented spectral, redox and kinetic data are compared with those reported for the corresponding prokaryotic enzymes and are discussed with respect to structure-function relationships and physiological role(s) of eukaryotic catalase-peroxidases.

\section{Materials and methods}

Magnaporthe grisea. The ascomycete Magnaporthe grisea, strain MA 829 (Cooke) was obtained from the internal collection of BOKU - University of Natural Resources and Applied Life Sciences, Vienna. It was first grown on MPG-agar plates (containing $20 \mathrm{~g}$ malt extract, $1 \mathrm{~g}$ peptone, $20 \mathrm{~g}$ glucose and $20 \mathrm{~g}$ agar in $1 \mathrm{~L}$ ) for 4-6 days at room temperature. For the isolation of RNA and activity monitoring it was grown in liquid medium with the same composition (without agar) at $25^{\circ} \mathrm{C}$ in a shaking incubator at $130 \mathrm{rpm}$ for 3 days. 
Sequence similarity searches - PeroxiBase. All available sequences of peroxidase genes and proteins have been systematically annotated, compared and analysed in PeroxiBase (http://peroxibase.isb-sib.ch/, see [20] for details). All sequence names used in this contribution correspond to the nomenclature of PeroxiBase where also links to the corresponding genes and genomes can be found. Name and identification number of the intracellular catalase-peroxidase from Magnaporthe grisea are MagKatG1 and 2288, respectively, the corresponding UniProt accession is A4R5S9.

Multiple sequence alignment. Multiple sequence alignment of fungal and bacterial KatG proteins was performed with ClustalX Version 2.0.5 [21]. Following optimised parameters were applied: Gonet protein weight matrix with gap opening penalty 8 , gap extension penalty 0.2 and gap separation distance of 4 . The aligned output was presented with Genedoc [22].

Promoter \& sub-cellular targeting prediction. Prediction of intron and native promoter location within the genomic DNA of Magnaporthe grisea strain 70-15 was performed in SoftBerry suite (http://www.softberry.com) using the ascomycete-specific parameters.

Cloning, heterologous expression and purification of recombinant MagKatG1. The cloning strategy of cDNA and complete katG1 gene is described in Supplemental material 1. Briefly, the complete gene was first maintained in TOPO vector (Invitrogen) and after modification it was expressed within pET21d vector (Novagen) allowing a His-tag fusion. Heterologous expression was achieved from E. coli BL21 DE3 Star cells (Invitrogen) at $16{ }^{\circ} \mathrm{C}$ and addition of hemin ( $10 \mu \mathrm{M}$ final $)$ concomitantly with IPTG (1 mM final) in the cultivation medium. Cells of $16 \mathrm{~h}$ old culture were centrifuged for $15 \mathrm{~min}$ at $6000 \mathrm{rpm}$ and pellets were resuspended in homogenisation buffer containing $50 \mathrm{mM}$ sodium phosphate, $\mathrm{pH} 8.0$, and protease inhibitors ( $1 \mathrm{mM}$ PMSF, $1 \mu \mathrm{g} / \mathrm{mL}$ leupeptin and $1 \mu \mathrm{g} / \mathrm{mL}$ pepstatin). Homogenisation was performed by two ultra-sonication cycles on Vibra-Cell Model CV17 (Sonics Materials Inc.): length of each cycle: $45 \mathrm{~s}$; pulser: $50 \%$; intensive cooling between the cycles. The crude homogenate was centrifuged for $20 \mathrm{~min}$ at $20,000 \times \mathrm{g}$ and the cleared supernatant was applied onto MCAC chromatography (Chelating Sepharose Fast Flow, GE Healthcare) loaded with $\mathrm{Ni}(\mathrm{II})$ ions (volume: $30 \mathrm{~mL}$ ). After loading the column was washed with $150 \mathrm{~mL}$ buffer A (50 mM sodium phosphate, $\mathrm{pH} 8.0$, containing $500 \mathrm{mM} \mathrm{NaCl}$ and protease inhibitors). Bound His-tagged protein was eluted with a linear gradient of buffer A to $100 \%$ buffer $\mathrm{B}(50 \mathrm{mM}$ sodium phosphate, $\mathrm{pH} 6.5$, containing $500 \mathrm{mM} \mathrm{NaCl}$ and $500 \mathrm{mM}$ imidazole). For final purification and determination of putative oligomeric structure of MagKatG1 gel permeation chromatography (Superdex 200 prep grade, GE Healthcare) was performed: volume: $250 \mathrm{~mL}$; sample volume: $1 \mathrm{~mL} ; 5 \mathrm{mM}$ sodium phosphate, $\mathrm{pH}$ 7.0, containing $0.15 \mathrm{M} \mathrm{NaCl}$; flow rate: $0.5 \mathrm{~mL} \mathrm{~min}^{-1}$; maximal pressure: $0.3 \mathrm{MPa}$.

Purity of obtained fractions was analysed with SDS PAGE under standard conditions (BioRad Mini-Protean, $12 \%$ separating gel) with gels being either stained with Coomassie Brilliant Blue or blotted onto nitrocellulose membrane (Amersham Biosciences) for detection of MagKatG1 by immunoblotting using a polyclonal antibody raised against catalaseperoxidase from Neurospora crassa [23].

To reveal the expression pattern of MagKatG1 native polyacrylamide gel electrophoresis with a linear gradient of $4-18 \%$ acrylamide was used. Native electrophoresis was run with $10 \mathrm{mM}$ Tris/HCl buffer, $\mathrm{pH}$ 8.3, containing $14.4 \mathrm{~g} / \mathrm{L}$ glycine (Mini-Protean apparatus, BioRad) at $150 \mathrm{~V}$ for $30 \mathrm{~min}$, followed by $65 \mathrm{~V}$ for $3 \mathrm{~h}$. Catalase staining was performed according to [24] with catalatically active bands ocurring as white bands on a dark- 
green background. Peroxidase activity staining was performed by using $o$-dianisidine as electron donor.

Mass spectrometric analysis. In order to analyse proteolytic degradation of MagKatG1 bands in SDS-PAGE were excised, destained, carbamidomethylated and digested with sequencing-grade bovine trypsin (Sigma-Aldrich). The extraction from gel pieces was performed in the same mode as described recently [25]. Extracts were taken to dryness in a Speed Vac concentrator and reconstituted with water containing $0.1 \%$ formic acid. Subsequent MALDI-TOF-MS analysis was performed on a Voyager-DE STR (Applied Biosystems) with $\alpha$-cyano-4-hydroxycinnamic acid (ACH) as matrix.

Electronic circular dichroism spectrometry and structure prediction. ECD spectra were recorded on a PiStar-180 Spectrometer equipped with a thermostatic cell holder (Applied Photophysics; Leatherhead, U.K.). For recording far-UV spectra (260-190 nm) the quartz cuvette had a path length of $1 \mathrm{~mm}$. Spectral bandwidth: $5 \mathrm{~nm}$; step size: $1 \mathrm{~nm}$; scan time: $624 \mathrm{~s}$; protein concentration: $4 \mu \mathrm{M}$ MagKatG1. Protein concentration was calculated from the known amino acid composition and absorption at $280 \mathrm{~nm}$ according to [26]. All ECD measurements were performed in $5 \mathrm{mM}$ phosphate buffer, $\mathrm{pH} 7.0$, at $25^{\circ} \mathrm{C}$. Each spectrum was automatically corrected with the baseline to remove birefringence of the cell. The instrument was flushed with nitrogen with a flow rate of $5 \mathrm{~L} \mathrm{~min}^{-1}$.

In addition the secondary structure of MagKatG1 was predicted with Psipred [27]. The 3D structure of MagKatG1 was modeled using EsyPred 3D [28] and KatG from Burkholderia pseudomallei (1MWV). The reliability of the obtained model was verified using What IF (http://swift.cmbi.ru.nl/servers/htmL/index.htmL).

Electronic UV-VIS spectroscopy. The UV-VIS spectrum of purified recombinant ferric MagKatG1 in $5 \mathrm{mM}$ phosphate buffer, $\mathrm{pH}$ 6.5, was routinely recorded on Zeiss Specord 10 diode array photometer in the range between $200-800 \mathrm{~nm}$ at $25^{\circ} \mathrm{C}$. We have determined the extinction coefficient at Soret band $\left(\varepsilon_{408 \mathrm{~nm}}=110,650 \mathrm{M}^{-1} \mathrm{~cm}^{-1}\right)$ for highly purified MagKatG1 from the slope of the linear correlation between $\mathrm{A}_{408 \mathrm{~nm}}$ and seven distinct protein concentrations (not shown). Ferrous MagKatG1 was produced by addition of sodium dithionite either directly or from a freshly prepared anaerobic stock solution in a glove box (Meca-Plex, Neugebauer) with a positive pressure of nitrogen (25 millibars). All solutions were made anaerobic by flushing with nitrogen gas (oxygen $<3 \mathrm{ppm}$ ) and stored in the glove box. The spectrum of the low-spin cyanide complex of MagKatG1 was recorded after mixing $7 \mu \mathrm{M}$ protein with $800 \mu \mathrm{M}$ cyanide in $5 \mathrm{mM}$ phosphate buffer, $\mathrm{pH}$ 6.5.

Spectroelectrochemistry. Determination of the standard reduction potential, $E^{\circ}$, of the $\mathrm{Fe}(\mathrm{III}) / \mathrm{Fe}$ (II) couple of MagKatG1 was carried out using a homemade OTTLE cell [29]. The three-electrode configuration consisted of a gold mini-grid working electrode (BuckbeeMears, Chicago, IL), a homemade $\mathrm{Ag} / \mathrm{AgCl} / \mathrm{KCl}_{\text {sat }}$ microreference electrode, separated from the working solution by a Vycor set, and a platinum wire as counter electrode. The reference electrode was calibrated against a saturated calomel electrode before each set of measurements. All potentials are referenced to the SHE. Potentials were applied across the OTTLE cell with an Amel model 2053 potentiostat/galvanostat. The constant temperature was maintained by a circulating water bath, and the OTTLE cell temperature was monitored with a $\mathrm{Cu}$-costan microthermocouple. UV-VIS spectra were recorded using a Varian Cary C50 spectrophotometer. Spectra of $28 \mu \mathrm{M}$ MagKatG1 equilibrated in $50 \mathrm{mM}$ sodium phosphate buffer, $\mathrm{pH} 7.0$, containing $10 \mathrm{mM} \mathrm{NaCl}$ were recorded at various applied potentials. The following electron mediators were used: $850 \mu \mathrm{M}$ methyl viologen, $3 \mu \mathrm{M}$ lumiflavine-3acetate, indigo disulfonate, phenazine methosulfate and methylene blue. Results were 
presented as Nernst plot that allowed calculation of the standard reduction potential, $E^{\circ}$, of the $\mathrm{Fe}(\mathrm{III}) / \mathrm{Fe}(\mathrm{II})$ couple MagKatG1 .

Kinetics and thermodynamics of formation of the MagKatG1-cyanide complex. In order to probe haem accessibility apparent bimolecular rate constants of complex formation between cyanide and ferric MagKatG1 were determined by convential stopped-flow spectroscopy (model SX-18MV Applied Photophysics, U.K.). For a total of $100 \mu \mathrm{L} /$ shot into the optical observation cell with $1 \mathrm{~cm}$ light path, the fastest time for mixing two solutions and recording the first data point was of the order of $1.3 \mathrm{~ms}$. Formation of low-spin cyanide complex was followed at $426 \mathrm{~nm}$, the Soret maximum difference between high-spin MagKatG1 and the cyanide complex. In a typical experiment, one syringe contained $2 \mu \mathrm{M}$ MagKatG1 in $5 \mathrm{mM}$ phosphate buffer, $\mathrm{pH} \mathrm{7.0,} \mathrm{and} \mathrm{the} \mathrm{second} \mathrm{syringe} \mathrm{contained} \mathrm{at} \mathrm{least} \mathrm{a} \mathrm{2.5-}$ fold excess of cyanide in $100 \mathrm{mM}$ phosphate buffer, $\mathrm{pH}$ 7.0. At high molar excess of cyanide over catalase-peroxidase, the formation of cyanide complex was too fast, and the majority of absorbance change occurred within the dead time of the instrument. As a consequence, pseudo-first order conditions could not be maintained over the whole concentration range. Three determinations were performed for each ligand concentration. The mean of the pseudofirst-order rate constants, $k_{\mathrm{obs}}$, was used in the calculation of the second-order rate constant obtained from the slope of a plot of $k_{\text {obs }}$ versus cyanide concentration. All measurements were performed at $25^{\circ} \mathrm{C}$.

Equilibrium binding of cyanide to MagKatG1 was studied by spectroscopic titration of $1 \mu \mathrm{M}$ enzyme in $100 \mathrm{mM}$ phosphate buffer, $\mathrm{pH} 7.0$, with increasing concentrations of cyanide $(1 \mu \mathrm{M}-800 \mu \mathrm{M})$. Enzyme spectrum was recorded before and after addition of constant volumes of cyanide solution and the free enzyme spectrum was substracted from the complex spectrum after correction for volume dilution. Plotting the ratio of cyanide concentration to absorbance difference between HS and LS MagKatG1 (peak maximum minus valley) against the cyanide concentration allowed determination of $K_{\mathrm{D}}$.

Overall kinetic parameters. Catalase activity was determined both polarographically using a Clark-type electrode (YSI 5331 Oxygen Probe) inserted into a stirred water bath (YSI $5301 \mathrm{~B}$ ) or spectrophotometrically by measuring the decomposition of hydrogen peroxide at $240 \mathrm{~nm}$ according to [30]. For spectrophotometrical measurement one unit was defined as the amount of enzyme catalyzing the conversion of $1 \mu \mathrm{mol} \mathrm{H}_{2} \mathrm{O}_{2} \mathrm{~min}^{-1}$ at an initial concentration of $15 \mathrm{mM} \mathrm{H}_{2} \mathrm{O}_{2}$ at $\mathrm{pH}$ optimum and $25^{\circ} \mathrm{C}$.

Peroxidase activity was monitored spectrophotometrically using $1 \mathrm{mM} \mathrm{H}_{2} \mathrm{O}_{2}$ and 5 $\operatorname{mM} \operatorname{ABTS}\left(\varepsilon_{414}=31.1 \mathrm{mM}^{-1} \mathrm{~cm}^{-1}\right)[31]$ or $5 \mathrm{mM}$ guaiacol $\left(\varepsilon_{470}=26.6 \mathrm{mM}^{-1} \mathrm{~cm}^{-1}\right)$ or $1 \mathrm{mM} \mathrm{o-}$ dianisidine $\left(\varepsilon_{460}=11.3 \mathrm{mM}^{-1} \mathrm{~cm}^{-1}\right)$ or $1 \mathrm{mM}$ pyrogallol $\left(\varepsilon_{430}=2.5 \mathrm{mM}^{-1} \mathrm{~cm}^{-1}\right)$. One unit of peroxidase was defined as the amount of enzyme that decomposes $1 \mu \mathrm{mol}$ of electron donor $\min ^{-1}$ at $\mathrm{pH}$ optimum and $25^{\circ} \mathrm{C}$.

Additionally, peroxidase activity with ethanol as 2-electron donor was determined at $340 \mathrm{~nm}$ in a coupled reaction using aldehyde dehydrogenase as described previously [32]. Chlorination and bromination activity of recombinant MagKatG1 was followed by halogenation of monochlorodimedon MCD $(100 \mu \mathrm{M})$ dissolved in $100 \mathrm{mM}$ phosphate buffer, $\mathrm{pH} 7.0$, containing $10 \mathrm{mM} \mathrm{H}_{2} \mathrm{O}_{2}$ and either $10 \mathrm{mM}$ bromide or $100 \mathrm{mM}$ chloride. Rates of halogenation were determined from the initial linear part of the time traces using an extinction coefficient for MCD at $290 \mathrm{~nm}$ of $19.9 \mathrm{mM}^{-1} \mathrm{~cm}^{-1}$ [33]. One unit was defined as the amount that decomposes $1 \mu \mathrm{mol}$ of $\mathrm{MCD} \min ^{-1}$ at $\mathrm{pH} 7.0$ and $25^{\circ} \mathrm{C}$. Iodide oxidation was followed at $353 \mathrm{~nm}$, i.e. absorbance maximum of triiodide $\left(\varepsilon=25.5 \mathrm{mM}^{-1} \mathrm{~cm}^{-1}\right)$ in $100 \mathrm{mM}$ phosphate buffer, $\mathrm{pH} 7.0$, containing $10 \mathrm{mM} \mathrm{H}_{2} \mathrm{O}_{2}$ and $10 \mathrm{mM}$ iodide at $\mathrm{pH} 7.0$ and $25{ }^{\circ} \mathrm{C}$ [34]. One unit was defined as the amount that produces $1 \mu \mathrm{mol}$ of $\mathrm{I}_{3}^{-} \min ^{-1}$ at $\mathrm{pH} 7.0$ and $25^{\circ} \mathrm{C}$. 
In all steady-state measurements at least three determinations for each electron donor concentration were performed and reactions were started by addition of MagKatG1.

\section{Results and Discussion}

Statistics from PeroxiBase clearly suggests that in eukaryotic organisms KatGs are predominantly spread among the fungal kingdom. A recent phylogenetic analysis [2] demonstrated the existence of two distinct types of fungal kat $G$ genes. Mainly phytopathogenic fungi (e.g. Magnaporthe grisea or Gibberella zeae) contain both paralogs, with katG1 most probably encoding an intracellular and katG2 an extracellular catalaseperoxidase.

Analysis and comparison of the whole genome of Magnaporthe grisea [16] with katG1 and katG2 showed a significant difference in the $\mathrm{G}+\mathrm{C}$ contents (for katG1 59.2\% versus $51.6 \%$ ) suggesting a lateral gene transfer (LGT) of kat $G$ genes from bacteria to a fungal progenitor as has been demonstrated for other fungi $[3,6]$. Interestingly, the rather high $\mathrm{G}+\mathrm{C}$ contents of MagkatG1 resembled that of various Burkholderia species (58-68\%) thereby indicating a putative proteobacterial ancestor. In order to answer the question whether only the katG1 gene or a longer genome portion was transferred by LGT, we have also analysed the putative promoter region of MagkatG1 with GENSCANW (http://genes.mit.edu/GENSCAN.htmL). A conserved 40 bp long promoter motif was identified at positions -1838 to -1799 (see PeroxiBase $I D=2288$ for further details). Moreover, a typical CGGAGT-box was found in positions -657 to -652 similar to a promoter region in the catB gene of Aspergillus oryzae [35]. The $\mathrm{G}+\mathrm{C}$ contents of this $1838 \mathrm{bp}$ long region is only $49.73 \%$, thus even lower than the average value for the entire Magnaporthe genome. This suggests that only the coding region was transferred via LGT from a proteobacterial into the fungal genome.

In order to probe whether expression of MagKatG1 is induced by oxidative stress, cultures of Magnaporthe grisea were grown in MPG in the absence and presence of hydrogen peroxide or peroxyacetic acid or paraquat (final concentrations: $0.5-2 \mathrm{mM}$ ) added in the middle exponential or early stationary growth phase, respectively. RT-PCR analysis of total RNA isolated from filtered mycelia allowed quantification of katG1-specific mRNA under various conditions. The RT-PCR signal intensities obtained from various cDNA samples (Figure 1) clearly demonstrated that katG1 is expressed constitutively. Only with paraquat the expression level was enhanced to $120 \%$ compared to standard conditions. This might suggest a role of intracellular MagKatG1 in continuous degradation of $\mathrm{H}_{2} \mathrm{O}_{2}$ deriving from fungal metabolism and is in contrast to MagKatG2 that - due to the presence of a (predicted) signal sequence - is located extracellularly and is produced on demand, i.e. its expression is significantly enhanced under oxidative stress conditions that could occur during attacking of plants [17].

Subsequently MagKatG1 was heterologously expressed and purified. The entire ORF (2217 bp) was cloned in TOPO vector (Invitrogen) using outer primers and modified by introducing of NcoI, AgeI and NotI restriction sites without affecting the coding sequence (Supplemental material 1). This allowed cloning in pET21d vector (Novagen) in frame with a C-terminal hexa-His-tag fusion. Heterologous expression of the recombinant plasmid pMZM1 was performed in E. coli strain BL21 DE3 Star (Invitrogen) at $16^{\circ} \mathrm{C}$ and in the presence of hemin avoided formation of inclusion bodies and produced recombinant protein with almost $100 \%$ haem occupancy. In average about $30 \mathrm{mg}$ of soluble KatG1 could be obtained by lysis 
activity of the eukaryotic enzyme was very small (Table 1 ), namely $\sim 0.4 \%$ and $\sim 15 \%$ of the NADH oxidase activity reported for Burkholderia pseudomallei [41] and Escherichia coli $\mathrm{KatG}$ [7].

Thermostability tests of MagKatG1 were performed in the range from $25^{\circ} \mathrm{C}$ to $65^{\circ} \mathrm{C}$ by incubating the enzyme at the corresponding temperature for defined time intervals followed by measuring the catalase and peroxidase activities at $25^{\circ} \mathrm{C}$ (Table 2). Comparison with equivalent data of bacterial counterparts [7] revealed that MagKatG1 is a mesophilic enzyme that is more thermostable than Synechocystis KatG or Burkholderia pseudomallei KatG [7]. Generally, the catalase activity is more susceptible to temperature-induced inactivation than the peroxidase activity. It has to be investigated whether the observed (limited) thermostability of the peroxidatic activity may be related to the fact that Magnaporthe grisea attacks predominantly various cultivars of rice which grow optimally only in subtropical climate.

Summing up, phytopathogenic fungi are unique in having two catalase-peroxidase (KatG) paralogs located either intracellularly (KatG1) or extracellularly (KatG2). The coding genes have been shown to derive from a lateral gene transfer from a (proteo)bacterial genome followed by gene duplication and diversification. MagKatG1 is the first eukaryotic catalaseperoxidase to be heterologously expressed in E. coli in high amount and purity with almost $100 \%$ haem occupancy. The acidic, mainly homodimeric oxidoreductase contains a predominantly five-coordinated high-spin haem $b$ with spectral and redox properties comparable to prokaryotic enzymes. Its overwhelming catalase activity is characterized by a $\mathrm{pH}$ optimum at $\mathrm{pH} 6.0$ and $k_{\mathrm{cat}}$ and $K_{\mathrm{M}}$ values of $7010 \mathrm{~s}^{-1}$ and $4.8 \mathrm{mM}$, respectively. The intracellular metalloenzyme is expressed constitutively and might contribute to continuous degradation of $\mathrm{H}_{2} \mathrm{O}_{2}$ deriving from fungal metabolism in the cytosol. In addition the bifunctional enzyme acts as versatile peroxidase with $\mathrm{pH}$ optimum in the range $\mathrm{pH} 5.0$ - 5.5 oxidising both one- (ABTS, o-dianisidine, pyrogallol, guaiacol) and two-electron donors ( $\mathrm{Br}^{-}$, $\left.\mathrm{I}^{-}\right)$at reasonable rates. However, similar to prokaryotic KatGs, the biochemical and physiological role of the peroxidase activity of fungal KatGs is unknown as is the nature of the (putative) endogenous electron donor.

\section{Acknowledgements}

This research was supported by the Austrian Science Foundation (FWF project P19793). We would like to thank Christian Würtz and Hanspeter Rottensteiner for providing us with KatGspecific antibody. 


\section{References}

1 Smulevich, G., Jakopitsch, C., Droghetti, E. and Obinger, C. (2006) Probing the structure and bifunctionality of catalase-peroxidase (KatG). J. Inorg. Biochem. 100, 568-585

2 Zamocky, M., Furtmüller, P.G. and Obinger, C. (2008) The evolution of catalases from bacteria to man. Antioxid. Redox. Signal 10, 1527-1548

3 Zamocky, M. (2004) Phylogenetic relationships in class I of the superfamily of bacterial, fungal, and plant peroxidases. Eur. J. Biochem. 271, 3297-3309

4 Passardi, F., Bakalovic, N., Teixeira, F.K., Margis-Pinheiro, M., Penel, C. and Dunand, C. (2007) Prokaryotic origins of the non-animal peroxidase superfamily and organelle mediated transmission to eukaryotes. Genomics 89, 567-579

5 Zamocky, M., Regelsberger, G., Jakopitsch, C. and Obinger, C. (2001) The molecular peculiarities of catalase-peroxidases. FEBS Letters 492, 177-182

6 Passardi, F., Zamocky, M., Favet, J., Jakopitsch, C., Penel, C., Obinger, C. and Dunand, C. (2007) Phylogenetic distribution of catalase-peroxidases: Are there patches of order in chaos? Gene 397, 101-113

7 Singh, R., Wiseman, B., Deemagarn, T., Jha, V., Switala, J., and Loewen, P.C. (2008) Comparative study of catalase-peroxidases (KatGs). Arch. Biochem. Biophys. 471, 207-214

8 Yamada, Y., Fujiwara, T., Sato, T., Igarashi, N. and Tanaka, N. (2002) The 2.0 A crystal structure of catalase-peroxidase from Haloarcula marismortui. Nat. Struct. Biol. 9, 691-695

9 Bertrand, T., Eady, N.A.J., Jones, J.N., Jesmin, J.M., Nagy, J.M., Jamart-Gregoire, B., Raven, E.L. and Brown, K.A. (2004) Crystal structure of Mycobacterium tuberculosis catalase-peroxidase. J. Biol. Chem. 279, 38991-38999

10 Ten-I, T., Kumasaka, T., Higuchi, W., Tanaka, S., Yoshimatsu, K., Fujiwara, T. and Sato, T. (2007) Expression, purification, crystallization and preliminary X-ray analysis of the Met244Ala variant of catalase-peroxidase (KatG) from the haloarchaeon Haloarcula marismortui. Acta Crystallogr. Sect. F Struct. Biol. Cryst. Commun. 63, 940-943

11 Fraaije, M. W., Roubroeks, H.P., Hagen, W.R. and van Berkel, W.J.H. (1996) Purification and characterization of an intracellular catalase-peroxidase from Penicillium simplicissimum. Eur. J. Biochem. 235, 192-198

12 Peraza, L. and Hansberg, W. (2002) Neurospora crassa catalases, singlet oxygen and cell differentiation. Biol. Chem. 383, 569-575

13 Paris, S., Wysong, D., Debeaupuis, J.-P., Shibuya, K., Philippe, B., Diamond, R.D. and Latgé, J.-P. (2003) Catalases of Aspergillus fumigatus. Infect. Immun. 71, 35513562

14 Scherer, M., Wei, H., Liese, R. and Fischer, R. (2002) Aspergillus nidulans catalaseperoxidase gene (cpeA) is transcriptionally induced during sexual development through the transcription factor StuA. Eukaryotic Cell 1, 725-735

15 Valent, B. and Chumley, F.G. (1994) Avirulence genes and mechanisms of genetic instability in the rice blast fungus. In Rice Blast Disease (Zeigle, R. S., Leong, S.A., and Teng, P.S., ed.), pp. 111-134, IRRI, Los Banos

16 Dean, R. A., Talbot, N.J., Ebbole, D.J., Farman, M.L., Mitchell, T.K., Orbach, M.J., Thon, M., Kulkarni, R., Xu, J.R., Pan, H., Read, N.D., Lee, Y.-H., Carbone, I., Brown, D., Yeon Yee Oh, Donofrio, N., Jun Seop Jeong, Darren M. Soanes, Slavica Djonovic, Elena Kolomiets, Cathryn Rehmeyer, Weixi Li, Michael Harding, Soonok Kim, MarcHenri Lebrun, Heidi Bohnert, Sean Coughlan, Jonathan Butler, Sarah Calvo, Li-Jun Ma, Robert Nicol, and Purcell, S., Nusbaum, C., Galagan, J.E. and Birren, B.W. 
(2005) The genome sequence of the rice blast fungus Magnaporthe grisea. Nature 434, 980-986

17 Zamocky, M., Jakopitsch, C., Vlasits, J. and Obinger, C. (2007) Fungal catalase peroxidases - a novel group of bifunctional oxidoreductases. J. Biol. Inorg. Chem. 12, S97

18 Mittler, R. (2002) Oxidative stress, antioxidants and stress tolerance. Trends Plant. Sci. 7, 405-410

19 Xue, C., Li, L., Seong, K. and Xu, J.-R. (2004) Fungal pathogenesis in the rice blast fungus Magnaporthe grisea. In Plant-Pathogen Interactions (Talbot, N. J., ed.), pp. 138-165, CRC Press, Boca Ralton

20 Passardi, F., Theiler, G., Zamocky, M., Cosio, C., Rouhier, N., Teixera, F., MargisPinheiro, M., Ioannidis, V., Penel, C., Falquet, L. and Dunand, C. (2007) PeroxiBase: The peroxidase database. Phytochemistry 68, 534-539

21 Larkin, M. A., Blackshields, G., Brown, N.P., Chenna, R., McGettigan, P.A., McWilliam, H., Valentin, F., Wallace, I.M., Wilm, A., Lopez, R., Thompson, J.D., Gibson, T.J. and Higgins, D.G. (2007) Clustal W and Clustal X version 2.0. Bioinformatics 23, 2947-2948

22 Nicholas, K. B. and Nicholas, H.B. (1997) Genedoc: a tool for editing and annotating multiple sequence alignments. Distributed by the author

23 Schliebs, W., Würtz, C., Kunau, W.-H., Veenhuis, M. and Rottensteiner, H.-P. (2006) A eukaryote without catalase-containing microbodies: Neurospora crassa exhibits a unique cellular distribution of its four catalases. Eukaryotic Cell 5, 1490-1502

24 Woodbury, W. A., Spencer, K. and Stahlmann, M.A. (1971) An improved procedure using ferricyanide for detecting catalase isozymes. Anal. Biochem. 44, 301-305

25 Kolarich, D., Altmann, F. and Sunderasan, E. (2006) Structural analysis of the glycoprotein allergen Hev b 4 from natural rubber latex by mass spectrometry. Biochim. Biophys. Acta 1760, 715-720

26 Gill, S. C. and von Hippel, P.H. (1989) Calculation of protein extinction coefficients from amino acid sequence data. Anal. Biochem. 182, 319-326

27 McGuffin, L. J., Bryson, K. and Jones, D.T. (2000) The PSIPRED protein structure prediction server. Bioinformatics 16, 404-405

28 Lambert, C., Leonard, N., De Bolle, X. and Depiereux, E. (2002) EsyPred3D: prediction of proteins 3D structures. Bioinformatics 18, 1250-1256

29 Battistuzzi, G., D’Onofrio, M., Borsari, M., Sola, M., Macedo, A. L., Moura, J. J. and Rodrigues, P. (2000) Redox thermodynamics of low-potential iron-sulfur proteins. J. Biol. Inorg. Chem. 5, 748-760

30 Roggenkamp, R., Sahm, W. and Wagner, F. (1974) Microbial assimilation of methanol induction and function of catalase in Candida boidinii. FEBS Letters 41, 283-286

31 Barr, D. P. and Aust, S.D. (1993) On the mechanism of peroxidase-catalyzed oxygen production. Arch. Biochem. Biophys. 303, 377-382

32 Zamocky, M., Herzog, C., Nykyri, L.M. and Koller, F. (1995) Site-directed mutagenesis of the lower parts of the major substrate channel of yeast catalase A leads to highly increased peroxidatic activity. FEBS Letters 367, 241-245

33 Kettle, A. J. and Winterbourn, C. C. (1994) Assays for the chlorination activity of myeloperoxidase. Methods Enzymol. 233, 502-512

34 Jakopitsch, C., Regelsberger, G., Furtmüller, P.G., Rüker, F., Peschek, G.A. and Obinger, C. (2001) Catalase-Peroxidase from Synechocystis is capable of chlorination and bromination reactions. Biochem. Biophys. Res. Commun. 287, 682-687 
35 Hisada, H., Sano, M., Hata, Y., Abe, Y., and Machida, M. (2008) Deletion analysis of the catalase-encoding gene (catB) promoter from Aspergillus oryzae. Biosci.

Biotechnol. Biochem. 72, 48-53

36 Jakopitsch, C., Rüker, F., Regelsberger, G., Dockal, M., Peschek, G.A., and Obinger, C. (1999) Catalase-Peroxidase from the cyanobacterium Synechocystis PCC 6803: cloning, overexpression in Escherichia coli, and kinetic characterization. Biol. Chem. 380, 1087-1096

37 Bellei, M., Jakopitsch, C., Battistuzzi, G., Sola, M. and Obinger, C. (2006) Redox thermodynamics of the ferric-ferrous couple of wild-type Synechocystis KatG and KatG(Y249F). Biochemistry 45, 4768-4774

38 Conroy, C. W., Tyma, P., Daum, P.H. and Erman, J.E. (1978) Oxidation-reduction potential measurements of cytochrome c peroxidase and $\mathrm{pH}$ dependent spectral transitions in the ferrous enzyme. Biochem. Biophys. Acta 537, 62-69

39 Jones, D. K., Dalton, D.A., Rosell, F.I. and Raven, E.L. (1998) Class I heme peroxidases: characterization of soybean ascorbate peroxidase. Arch. Biochem. Biophys. 360, 173-178

40 Engleder, M., Regelsberger, G., Jakopitsch, C., Furtmüller, P.G., Rüker, F., Peschek, G.A. and Obinger, C. (2000) Nucleotide sequence analysis, overexpression in Escherichia coli and kinetic characterization of Anacystis nidulans catalase-peroxidase. Biochimie 82, 211-219

41 Singh, R., Wiseman, B., Deemagarn, T., Donald, L.J., Duckworth, H.W., Carpena, X., Fita, I. and Loewen, P.C. (2004) Catalase-peroxidases (KatG) exhibit NADH oxidase activity. J. Biol. Chem. 279, 43098-43106 
Table 1 Selected kinetic parameters of recombinant MagKatG1. Presented are average values of typical clones. Kinetic traces are presented in Supplemental material 6.

\begin{tabular}{|c|c|c|}
\hline Sample (clone) & Activity parameter & Data (average values) \\
\hline $\mathrm{M} 133$ & $K_{\mathrm{M}}\left(\mathrm{H}_{2} \mathrm{O}_{2}\right)$ & $(4.8 \pm 0.4) \mathrm{mM}^{-1}$ \\
\hline $\mathrm{M} 133$ & $k_{\text {cat }}\left(\mathrm{H}_{2} \mathrm{O}_{2}\right)$ & $(7010 \pm 230) \mathrm{s}^{-1}$ \\
\hline $\mathrm{M} 133$ & $k_{\text {cat }} / \mathrm{K}_{\mathrm{M}}\left(\mathrm{H}_{2} \mathrm{O}_{2}\right)$ & $(1.46 \pm 0.06) \times 10^{6} \mathrm{M}^{-1} \mathrm{~s}^{-1}$ \\
\hline $\mathrm{M} 133+\mathrm{M} 134+\mathrm{M} 166+\mathrm{M} 167$ & catalatic activity & $(3430 \pm 280) \mathrm{U} \mathrm{mg}^{-1}$ \\
\hline $\mathrm{M} 133+\mathrm{M} 134+\mathrm{M} 166+\mathrm{M} 167$ & $\begin{array}{c}\text { peroxidatic activity } \\
\text { (o-dianisidine) }\end{array}$ & $(14.2 \pm 4.6) \mathrm{U} \mathrm{mg}^{-1}$ \\
\hline $\mathrm{M} 133+\mathrm{M} 134+\mathrm{M} 166+\mathrm{M} 167$ & peroxidatic activity $(\mathrm{ABTS})$ & $(32.3 \pm 2.1) \mathrm{U} \mathrm{mg}^{-1}$ \\
\hline $\mathrm{M} 133+\mathrm{M} 134+\mathrm{M} 166+\mathrm{M} 167$ & $\begin{array}{c}\text { peroxidatic activity } \\
\text { (guaiacol) }\end{array}$ & $(2.7 \pm 0.4) \mathrm{U} \mathrm{mg}^{-1}$ \\
\hline $\mathrm{M} 133+\mathrm{M} 134+\mathrm{M} 166+\mathrm{M} 167$ & $\begin{array}{c}\text { peroxidatic activity } \\
\text { (pyrogallol) }\end{array}$ & $(3.3 \pm 0.3) \mathrm{U} \mathrm{mg}^{-1}$ \\
\hline $\mathrm{M} 133+\mathrm{M} 134+\mathrm{M} 166+\mathrm{M} 167$ & chlorination of MCD* & $(0.36 \pm 0.06) \mathrm{U} \mathrm{mg}^{-1}$ \\
\hline $\mathrm{M} 133+\mathrm{M} 134+\mathrm{M} 166+\mathrm{M} 167$ & bromination of MCD* & $(2.56 \pm 0.11) \mathrm{U} \mathrm{mg}^{-1}$ \\
\hline $\mathrm{M} 133+\mathrm{M} 134+\mathrm{M} 166+\mathrm{M} 167$ & iodination of MCD* & $(0.07 \pm 0.02) \mathrm{U} \mathrm{mg}^{-1}$ \\
\hline $\mathrm{M} 133+\mathrm{M} 166$ & (per)oxidation of ethanol & $(0.3 \pm 0.1) \mathrm{U} \mathrm{mg}^{-1}$ \\
\hline $\mathrm{M} 133+\mathrm{M} 166$ & NADH oxidase & $(2.2 \pm 0.5) \mathrm{U} \mu \mathrm{mol} \mathrm{haem}^{-1}$ \\
\hline $\mathrm{M} 133$ & $K_{\mathrm{D}}$ cyanide & $(1.4 \pm 0.3) \mu \mathrm{M}^{-1}$ \\
\hline $\mathrm{M} 133$ & $k_{\text {on }}$ cyanide & $(9.0 \pm 0.4) \times 10^{5} \mathrm{M}^{-1} \mathrm{~s}^{-1}$ \\
\hline $\mathrm{M} 133$ & $k_{\text {off }}$ cyanide & $(1.4 \pm 0.4) \mathrm{s}^{-1}$ \\
\hline
\end{tabular}

* MCD has been demonstrated not to function as electron donor for recombinant MagKatG1. 
Table 2 Thermostability of recombinant MagKatG1 (clones M133 and M166). n. d., not determined.

\begin{tabular}{|c|c|c|}
\hline Temperature & Loss of catalase activity & Loss of ABTS-peroxidase activity \\
\hline $40{ }^{\circ} \mathrm{C}$ & $95 \%$ after $22 \mathrm{~h}$ & stable, $<10 \%$ loss after $48 \mathrm{~h}$ \\
\hline $45^{\circ} \mathrm{C}$ & $95 \%$ after $330 \mathrm{~min}$ & stable, $<10 \%$ loss after $28 \mathrm{~h}$ \\
\hline $50{ }^{\circ} \mathrm{C}$ & $95 \%$ after $48 \mathrm{~min}$ & stable, $<10 \%$ loss after $28 \mathrm{~h}$ \\
\hline $55^{\circ} \mathrm{C}$ & $95 \%$ after $15 \mathrm{~min}$ & $\mathrm{n}$. d. \\
\hline $60{ }^{\circ} \mathrm{C}$ & $95 \%$ after $8 \mathrm{~min}$ & $50 \%$ after $7 \mathrm{~h}$ \\
\hline $65{ }^{\circ} \mathrm{C}$ & $95 \%$ after $1 \mathrm{~min}$ & $50 \%$ after $4 \mathrm{~h}$ \\
\hline
\end{tabular}




\section{LEGENDS TO FIGURES}

Figure 1 DNA electrophoresis ( $0.85 \%$ agarose) of RT-PCR products isolated from Magnaporthe grisea grown under standard conditions (lane 1) or oxidative stress induced by addition of $0.1 \mathrm{mM}$ paraquat (lane 2 ) or $0.3 \mathrm{mM}$ peroxyacetic acid (lane 3 ). Lane 4 : amplification of whole gene after induction of oxidative stress with paraquat; lane 5: molar mass standards with size given in base pairs (bp). In lanes 1-3 the same amount of RT-PCR product was loaded.

Figure 2 (A) SDS PAGE of recombinant MagKatG1 purified from E. coli BL21 DE3 Star homogenate. Lane 1: Coomassie Brilliant Blue stained crude extract; lane 2: pool from MCAC affinity column fractions 4-6; lane 3: pool from MCAC affinity column fractions 7 10; lane 4: protein from main elution peak of Superdex 200 chromatography (i.e. sample from lane $\underline{3}$ purified over a second column); lanes $5 \& 6$ : Western blot analysis using a polyclonal antibody raised against NcKatG1, lane 5: MCAC fractions $4-6$ (corresponding to CBB - lane 2), lane 6: MCAC fractions 7 - 10 (corresponding to $\mathrm{CBB}$ - lane 3). (B) Active staining on catalase (lanes $1 \& 2$ ) and peroxidase activity (lanes $3 \& 4$ ): lane 1: pool from MCAC fractions $7-10$; lane 2: pool from main peak of Superdex 200 chromatography (sample from lane 1 further purified); lane 3: pool from MCAC fractions 7-10; lane 4: pool from main peak of Superdex 200 (sample from lane 3 further purified). Bovine liver catalase (Sigma) and Comamonas testosteroni KatG (PeroxiBase ID 5351) were used as native standards. Molar mass of standard proteins is given in $\mathrm{kDa}$.

Figure 3 (A) Electronic UV-VIS and far-UV ECD spectrum (inset) of purified recombinant MagKatG1 (black line, $4.2 \mu \mathrm{M}$ ) in $5 \mathrm{mM}$ phosphate buffer, $\mathrm{pH}$ 7.0. For comparison the corresponding spectra of SynKatG (grey line) recorded under identical conditions are depicted. (B) Homology model of the 3D structure of MagKatG1 monomer revealed by EsyPred [28]. An overlay with the known structure of KatG from Burkholderia pseudomallei (PDB code $1 \mathrm{MWV}$ ) is presented. The figure was rendered by Swiss PDB Viewer.

Figure 4 Spectral characterisation of recombinant MagKatG1 (black line) in comparison with prokaryotic SynKatG (grey line). Arrows indicate peak maxima. (A) Ferric proteins in $5 \mathrm{mM}$ sodium phosphate buffer, $\mathrm{pH} 7.0$, and $25^{\circ} \mathrm{C}$. (B) Ferrous proteins in $5 \mathrm{mM}$ sodium phosphate buffer, pH 7.0, and $25^{\circ} \mathrm{C}$. (C) Low-spin cyanide complexes obtained by mixing of ferric proteins with $800 \mu \mathrm{M} \mathrm{NaCN}$ in $5 \mathrm{mM}$ sodium phosphate buffer, $\mathrm{pH} 7.0$, and $25^{\circ} \mathrm{C}$.

Figure 5 Electronic spectra of catalase-peroxidase from Magnaporthe grisea obtained at various applied potentials in spectroelectrochemical experiments. Spectra were recorded at $25{ }^{\circ} \mathrm{C}$. The corresponding Nernst plot is reported in the inset, where $\mathrm{X}$ stands for: $\left[\left(\mathrm{A}_{\lambda \mathrm{red}}{ }^{\text {Max }}\right.\right.$ $\left.\left.\mathrm{A}_{\lambda \text { red }}\right) /\left(\mathrm{A}_{\lambda_{\text {ox }}}{ }^{\mathrm{Max}}-\mathrm{A}_{\lambda \mathrm{ox}}\right)\right], \lambda_{\text {ox }}=406 \mathrm{~nm}$ and $\lambda_{\text {red }}=435 \mathrm{~nm}$. Conditions: sample volume: $1 \mathrm{~mL} ; 28$ $\mu \mathrm{M}$ protein in $50 \mathrm{mM}$ phosphate buffer, $\mathrm{pH} 7.0$, containing $10 \mathrm{mM} \mathrm{NaCl} ; 850 \mu \mathrm{M}$ methyl viologen and $3 \mu \mathrm{M}$ lumiflavine-3-acetate, indigo disulfonate, phenazine methosulfate and methylene blue.

Figure 6 Kinetics and thermodynamics of cyanide binding to recombinant MagKatG1. (A) Spectral transition showing the formation of the low spin cyanide complex. The reaction of 2 $\mu \mathrm{M}$ ferric MagKatG1 with $30 \mu \mathrm{M}$ cyanide was measured in the conventional stopped-flow mode. Arrows indicate changes of absorbance with time. Conditions: $50 \mathrm{mM}$ phosphate buffer, $\mathrm{pH} 7.0$, and $25^{\circ} \mathrm{C}$; (B) Typical time trace at $423 \mathrm{~nm}$ with single-exponential fit; (C) Dependence of $k_{\mathrm{obs}}$-values from the cyanide concentration. The association rate constant $k_{\mathrm{on}}$ was calculated from the slope, the dissociation rate constant $k_{\text {off }}$ from the intercept; (D) Hanes 
plot deduced from titration of MagKatG1 with increasing concentration of cyanide. Conditions: $7 \mu \mathrm{M}$ MagKatG1 in $50 \mathrm{mM}$ phosphate buffer, $\mathrm{pH} 7.0$, and $25{ }^{\circ} \mathrm{C}$.

Figure $7 \mathrm{pH}$-profile of catalase and peroxidase activities of recombinant MagKatG1 (clone M133). Concentration of MagKatG1 was $0.2 \mu \mathrm{M}$ and all measurements were performed at $25^{\circ} \mathrm{C}$ in $100 \mathrm{mM}$ phosphate or citrate buffers in the range between $\mathrm{pH} 3.0-9.0$. 
B Biochemical Journal Immediate Publication. Published on 10 Nov 2008 as manuscript BJ20081478

1

$2 \quad 3$

4

5

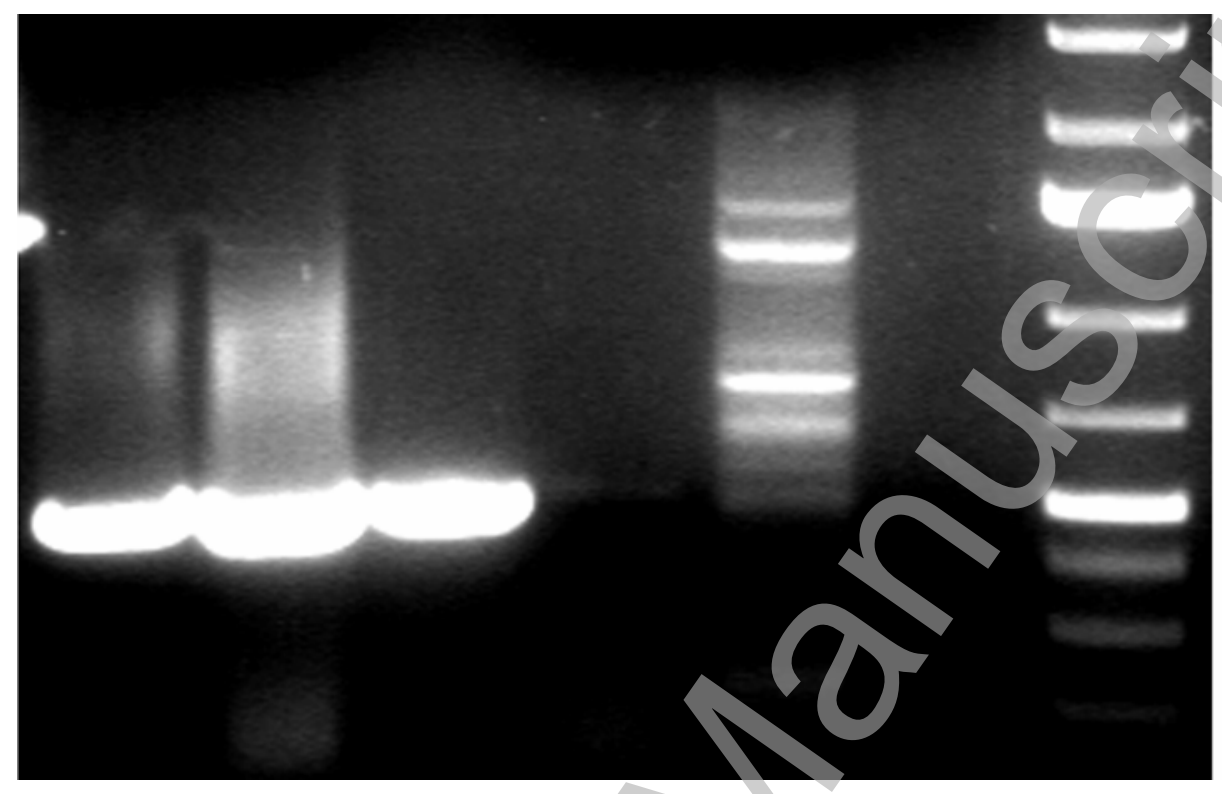

3000

2000

1500

1000

700

500

400

300

Zamocky et al, Figure 1

Licenced copy. Copying is not permitted, except with prior permission and as allowed by law. (C) 2008 The Authors Journal compilation (C) 2008 Portland Press Limited 
A

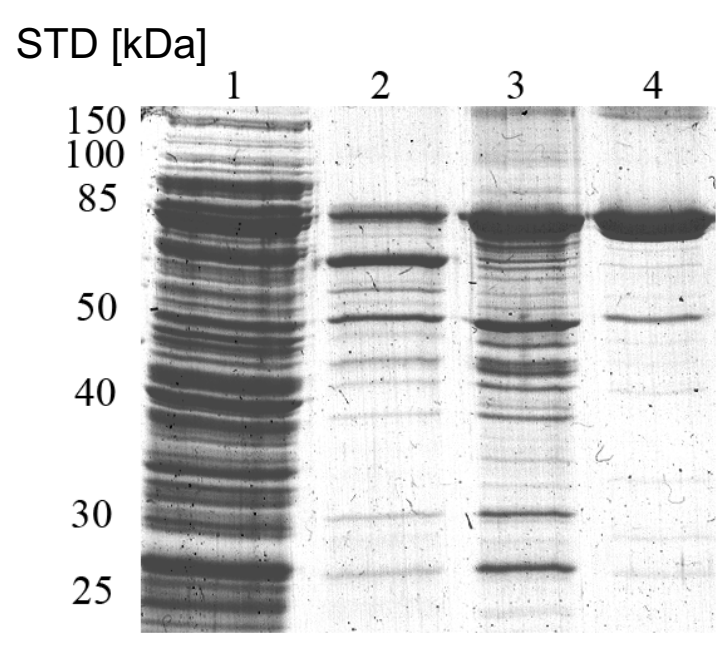

B

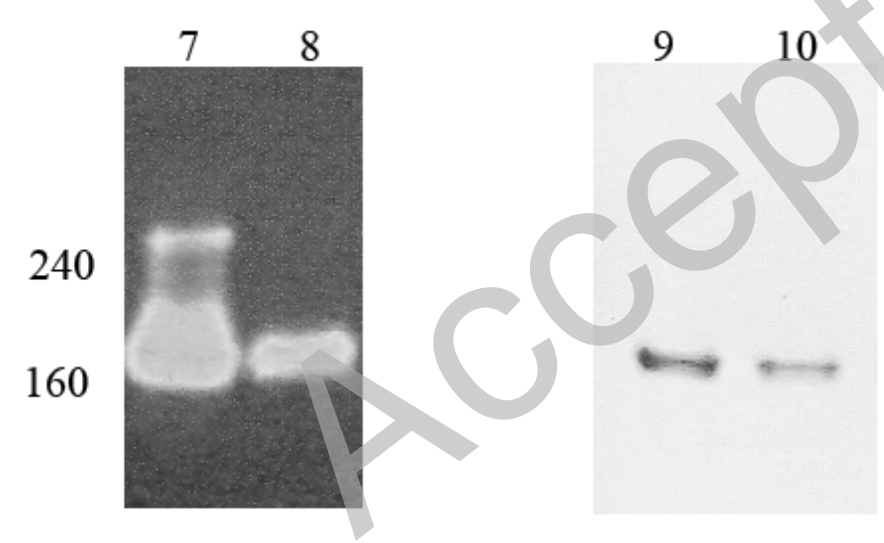

main bands used for MS analysis (kDa)

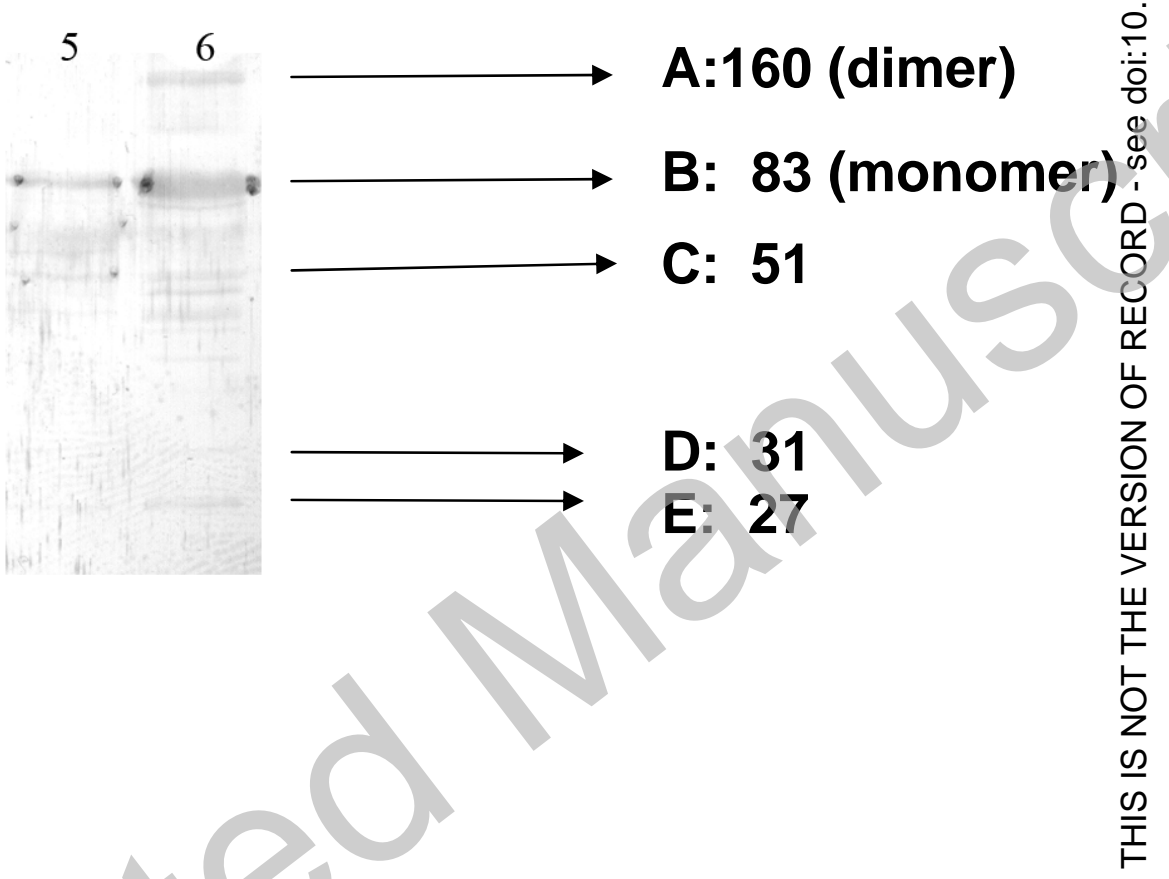

Zamocky et al, Figure 2

Licenced copy. Copying is not permitted, except with prior permission and as allowed by law. (C) 2008 The Authors Journal compilation (C) 2008 Portland Press Limited 


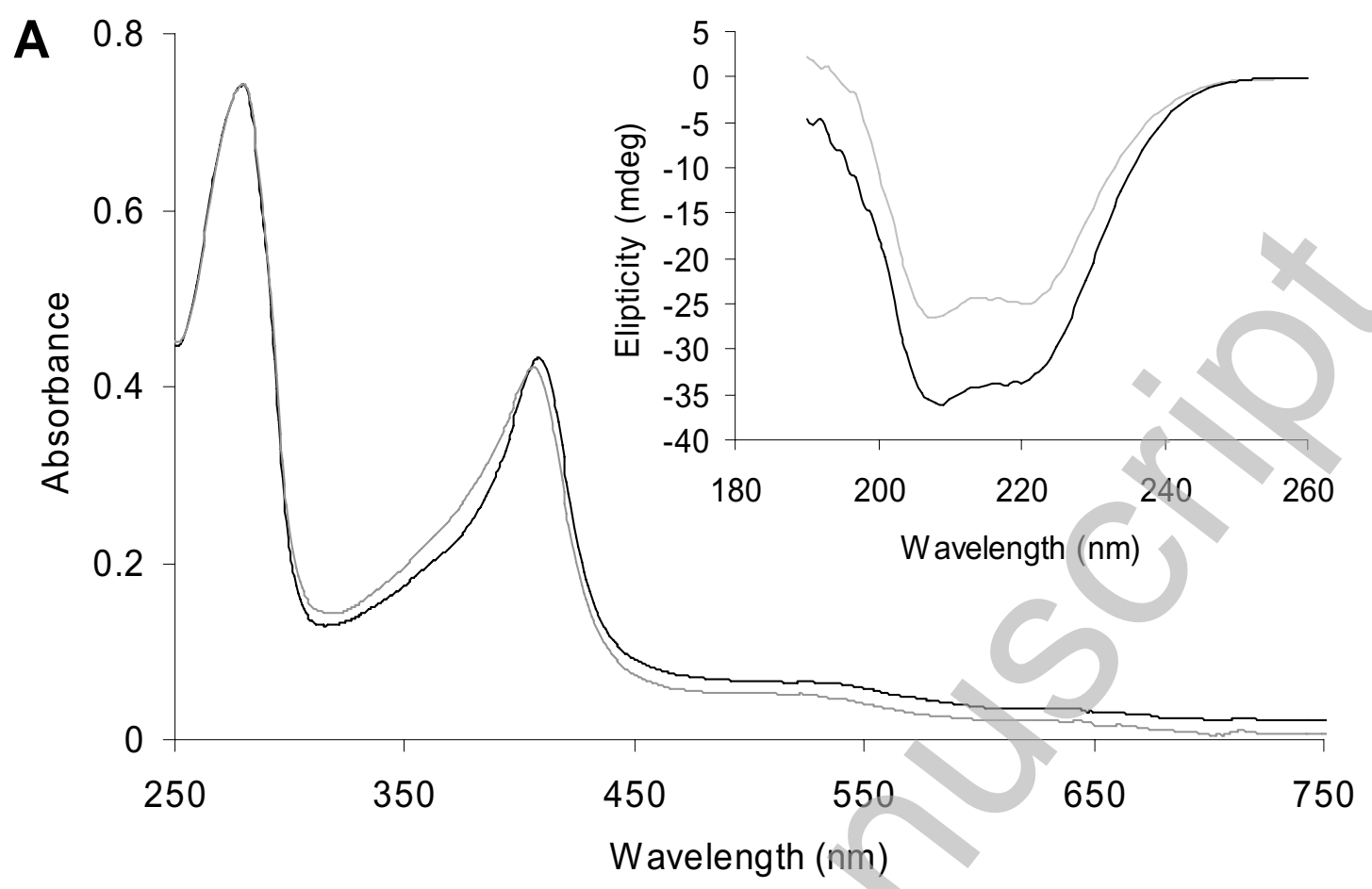

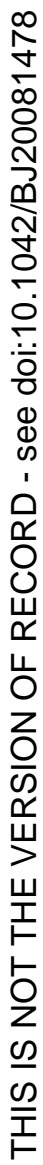

B
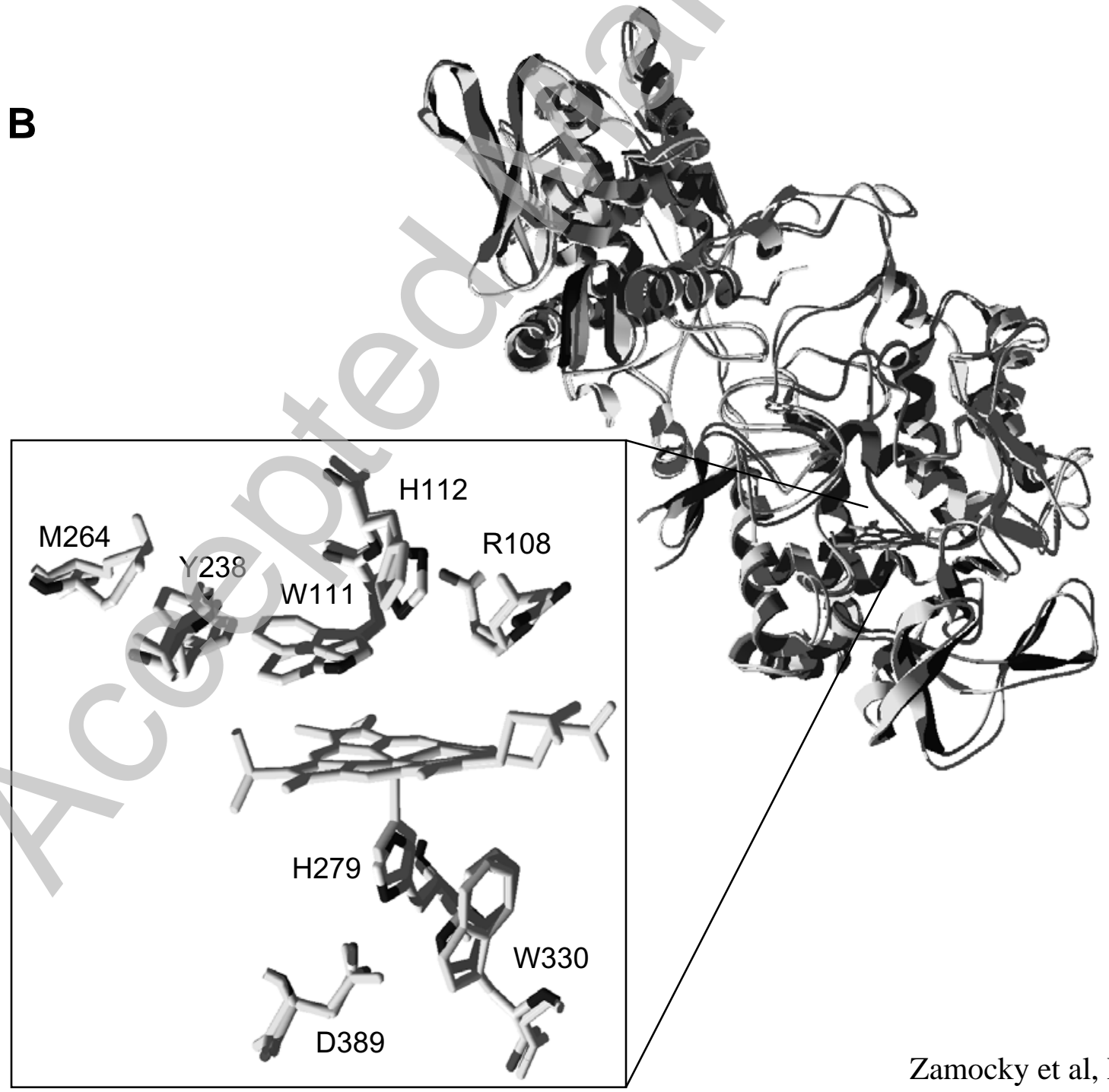

Zamocky et al, Figure 3

Licenced copy. Copying is not permitted, except with prior permission and as allowed by law. 
A

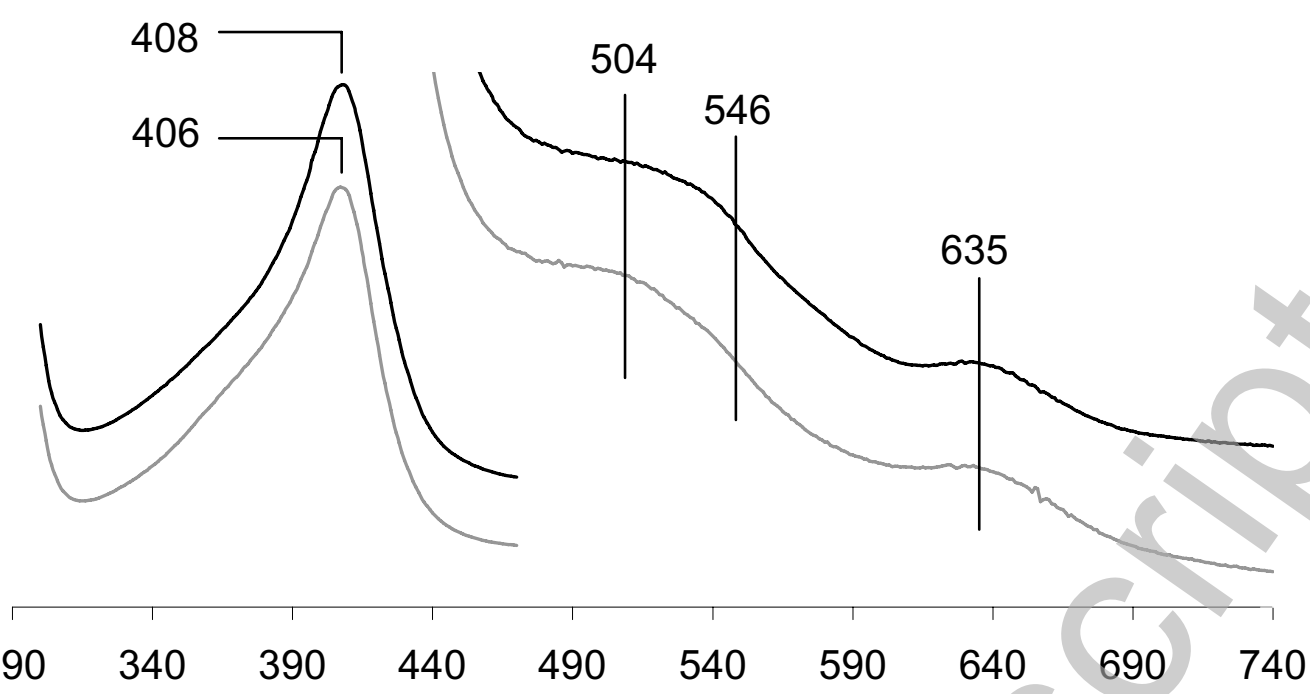

B

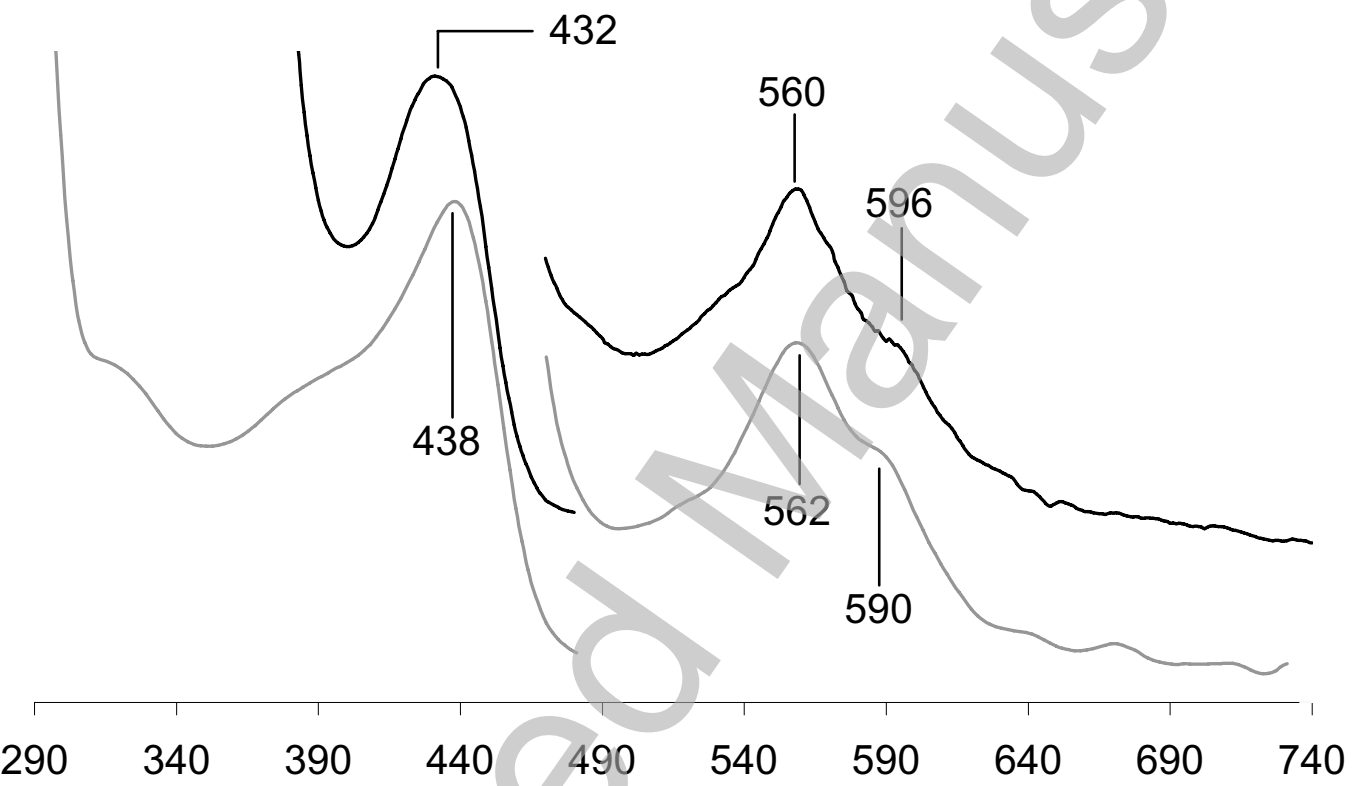

C

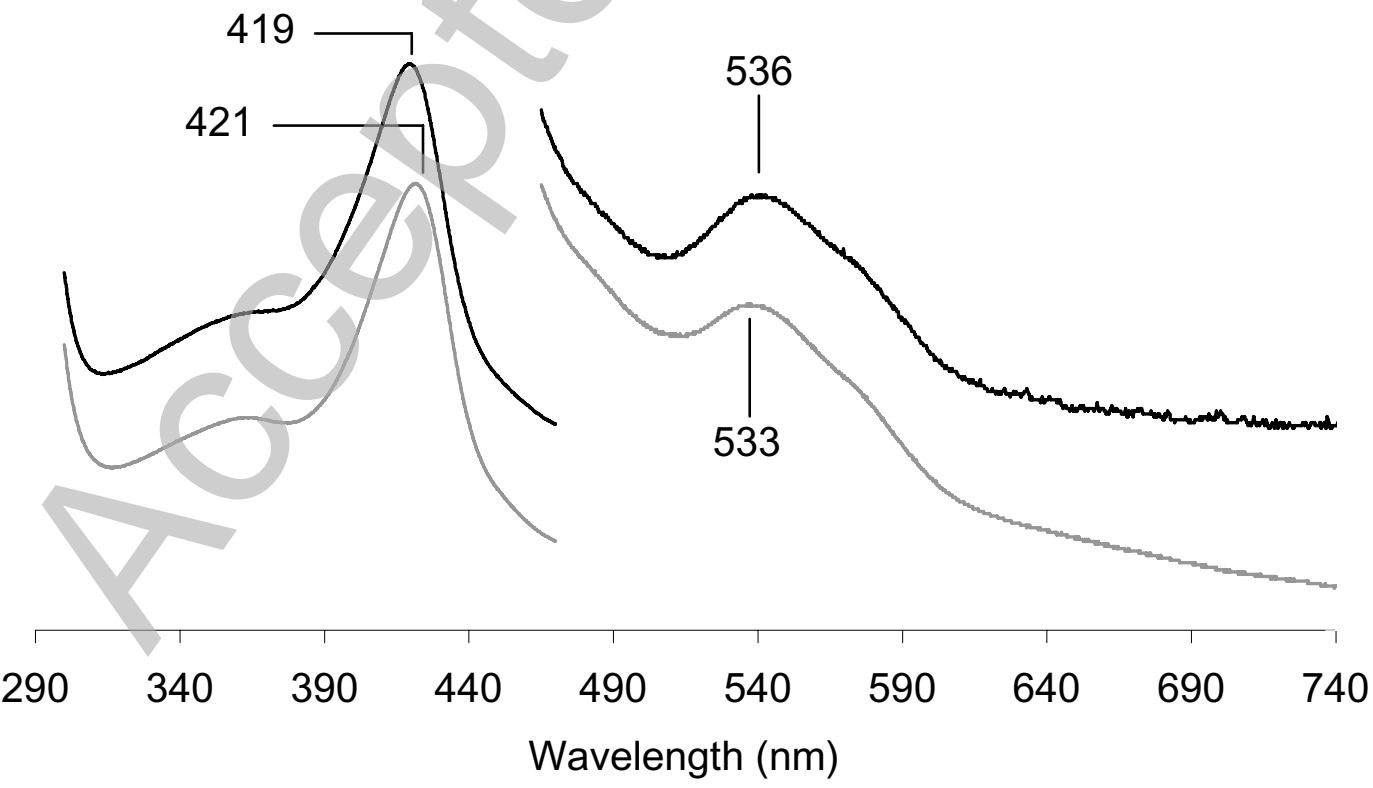

Zamocky et al, Figure 4 


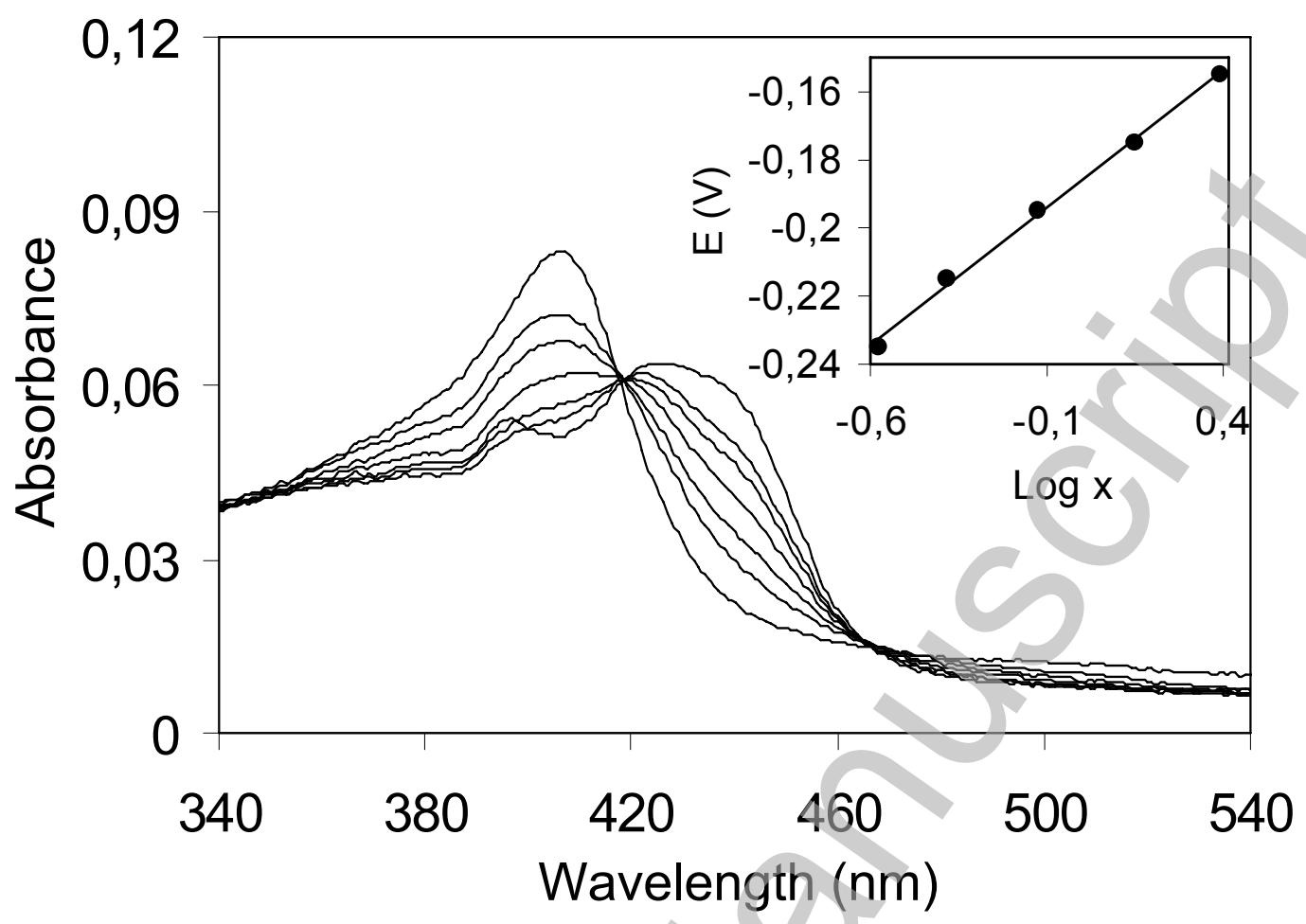

Zamocky et al, Figure 5 

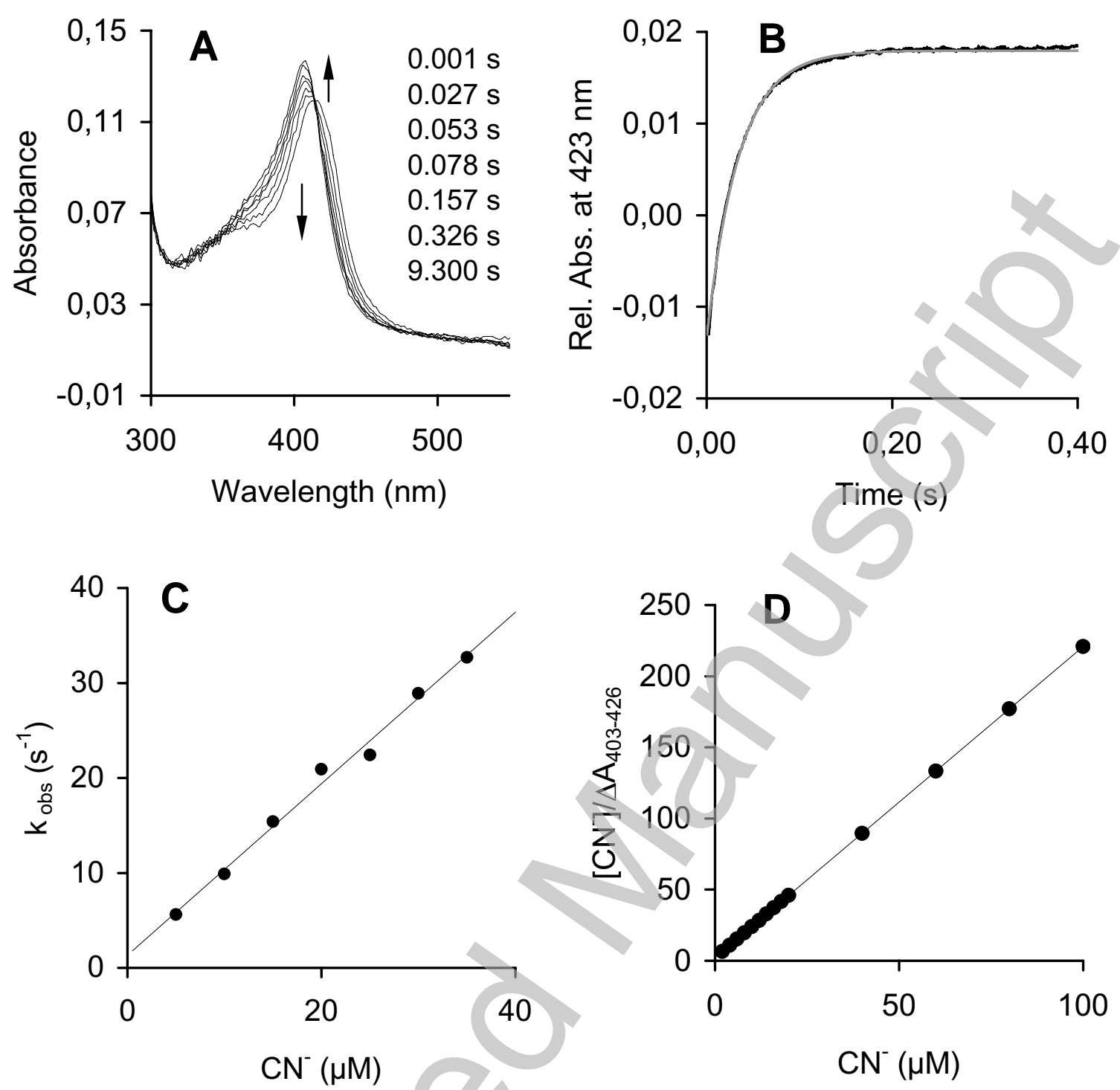

Zamocky et al, Figure 6 

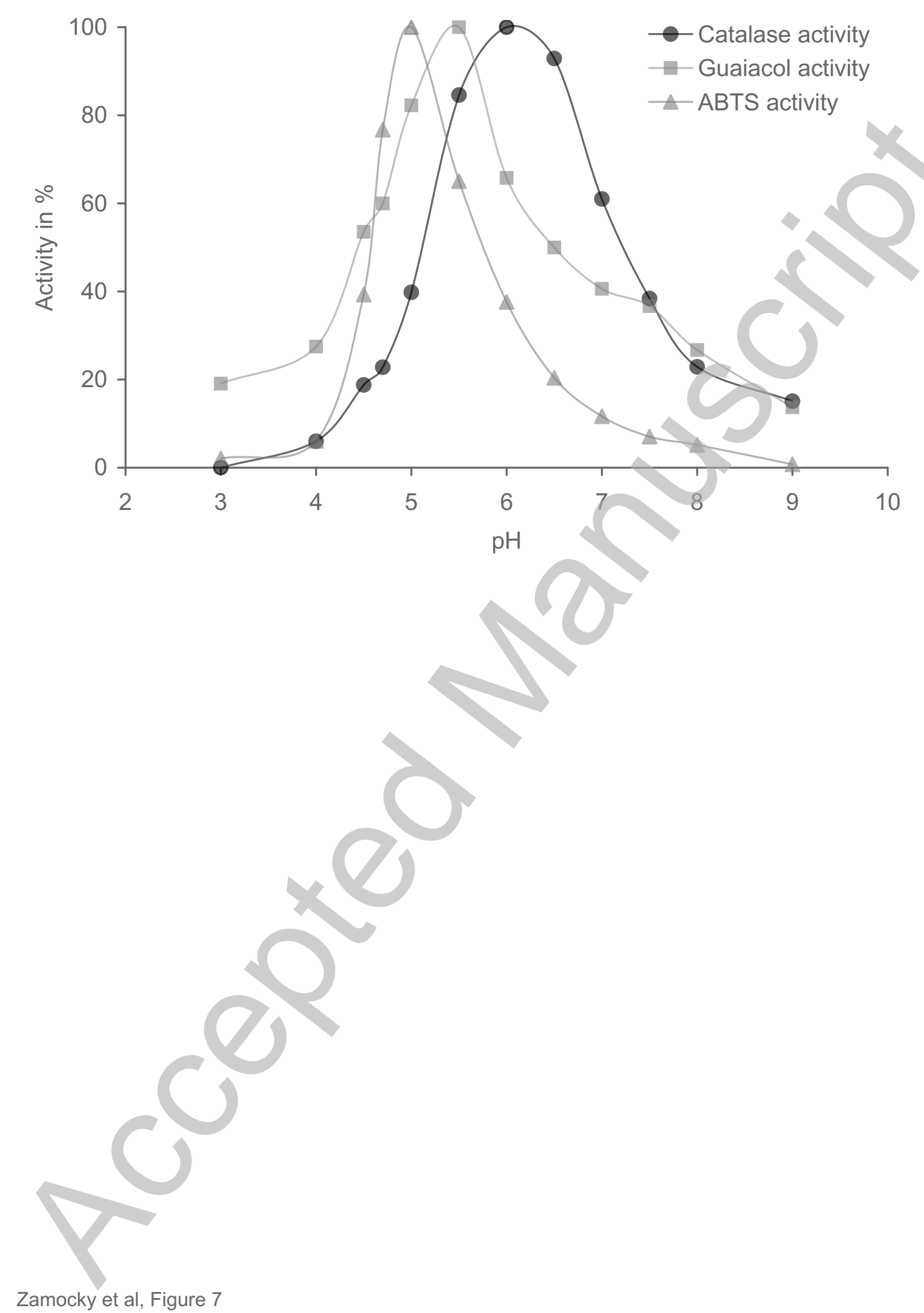

Licenced copy. Copying is not permitted, except with prior permission and as allowed by law. 